\title{
MANAGEMENT IDEOLOGIES AND ORGANIZATIONAL SPIRITUALITY: A TYPOLOGY ${ }^{1}$
}

\author{
MIGUEL PINA E CUNHA \\ Faculdade de Economia \\ Universidade Nova de Lisboa \\ Rua Marquês de Fronteira, 20 \\ 1099-038 Lisboa - Portugal \\ Tel: +351-212 822725 \\ Fax: +351-213 873973 \\ E-mail: mpc@fe.unl.pt \\ ARMÉNIO REGO \\ Universidade de Aveiro \\ Departamento de Economia, Gestão e Engenharia Industrial \\ Campus de Santiago \\ 3810-193 Aveiro- Portugal \\ Tel: +351-234 370024 \\ Fax: +351-234 370215 \\ arego@egi.ua.pt \\ TERESA D'OLIVEIRA \\ Instituto Superior de Psicologia Aplicada \\ Rua Jardim do Tabaco, 34 \\ 1149-041 Lisboa - Portugal \\ TEL +351-218 811700 \\ FAX: +351-218 860954 \\ Teresa.Oliveira@ispa.pt
}

\footnotetext{
${ }^{1}$ An initial version of this paper was first presented at the $2^{\text {nd }}$ European Meeting on Psychology and Ethics, Lisbon, November 2003. The first author gratefully acknowledges support from Instituto Nova Forum.
} 
MANAGEMENT IDEOLOGIES AND ORGANIZATIONAL SPIRITUALITY:

A TYPOLOGY

\begin{abstract}
The topic of spirituality is gaining an increasing visibility in organization studies. It is our contention that every theory of organization is a theory of organizational spirituality. Based on Barley and Kunda’s 1992 Administrative Science Quarterly article, we discuss the evolution of management theories as spirituality theories. From such analysis, we suggest that there may be both a meaningful/liberating and an instrumental/exploitative side in the relationship between organizations and spirituality. Such a possibility is illustrated with a typology that advances four possible types of organizations regarding spirituality: the soulful organization, the holistic organization, the ascetic organization, and the professional organization. The expression of spirituality in each of these forms is discussed with the aim of contributing to a theoretically-based analysis of organizational spirituality.
\end{abstract}

Keywords: management ideologies, organizational spirituality, religion 
The world of organizations is undergoing a period of change from employment relationships characterized by security, continuity and loyalty, to relationships denoted by exchange and future employability (Arthur \& Rousseau, 2001), from an era in which employee's responsibilities were those of loyalty, attendance, satisfactory performance and compliance with authority, to a time in which people are exhorted to be entrepreneurs, innovators, enactors of change and excellent performers (Schalk \& Rousseau, 2001). These changes have made clear the need to view people as the creators of knowledge and thus as a valuable organizational resource (Pfeffer, 1994). Considering both the need to treat people with dignity and the relationships between psychological well-being and organizational results (Wright \& Cropanzano, 2000), people should not be treated as "human resources" (Burroughs \& Eby, 1998) but as integral human beings. To treat people in their entirety means to understand and correspond to both their material and immaterial needs. These may be said to include spiritual needs.

The fulfillment of spiritual needs in the workplace has been associated with "guiding principles based on spirituality, ethics, and values which in turn translate into daily actions and decisions” (Burroughs \& Eby, 1998: 512). This and other similar ideas created a momentum for the topic of spirituality in recent years as a relevant one in the organizational literature. As observed by Susie Tompkins of Esprit, "the 1980s were all about style and lifestyle (...) The 1990s are about soul-searching.” (in Nichols, 1994: 52). More than advocacy of the organizational spirituality topic, what is now lacking is a theoretically-informed analysis of organizational spirituality.

This lack of theoretical development may result from the fact that spirituality as an organizational scholarly topic is a fairly recent discovery (Ashmos \& Duchon, 2000). 
However, in their history of the firm, Micklethwait and Woolridge suggest that this is a lasting relationship in the world of business. They quote Francesco di Marco Datini, a 12th century Italian businessman, whose business motto reads "for God and for profit" (Micklethwait \& Woolridge, 2003: 10). In this article we argue that every management theory is a theory of organizational spirituality. We depart from Vaill's (1998) argument that organizations are inherently spiritual, and explore the spiritual underpinnings of management theories: as will be discussed, in some theories the spiritual element is explicitly considered as an organizational dimension; in other theories, spirituality is viewed as lying outside of the range of managerial concerns.

With the intention of exploring the representation of spirituality in management ideologies, we have organized the paper as follows. We start by defining spirituality and by distinguishing it from religion. Then, based on Barley and Kunda’s (1992) research, we analyze the evolution of management theories as theories of organizational spirituality. From such analysis, we suggest that there may be both a positive and a negative side in the many forms of organizational spirituality.

This paper contributes to the organizational literature in several ways. It suggests that organizational theories can be addressed from a spiritual perspective. Spiritual elements have been explicitly articulated in the classical theories, but removed from the more recent ones. The paper explores why this has happened. It also critically addresses the recent scholarly interest with the organizational spirituality topic. Possible approaches to understanding organizational spirituality are also advanced and critically analyzed. In summary, the paper articulates a theoretically informed model of organizational spirituality and suggests that spirituality, in itself, is neither a source of employee 
freedom nor a vehicle for alienation. It can be both things, depending on how it is used and developed in a given organizational setting.

\section{SPIRITUALITY AND MANAGEMENT IDEOLOGIES}

A long yet turbulent relationship between spirituality and management can be identified. Organization theories tend to be approached from a secular perspective. Sometimes, however, researchers have noted the need to include religious and/or spiritual elements in their analysis. Among these, Sandelands wrote that "Without God (...) management theory is nonsense and we who teach it are charlatans or worse.” (2003: 170); and Tinsley (2002) draws managerial lessons from the Old Testament Book of Proverbs. In this paper, and drawing on the work of McCormick (1994), spirituality is defined as the inner experience of the individual when actively attempting to harmonize his/her actual life with life's deeper motivations. This individual attempt may take an institutional form (i.e. a religious form, meaning the adherence to dogma and the practice of rituals), or not. This traces the difference between religion and spirituality.

In this paper, we are more interested in dealing with spirituality than with religion. Mitroff (Mitroff \& Denton, 1999a; Mitroff, 2003), argued that religion is an inappropriate form of expression in the workplace (except in terms of religious accommodation; see Cash \& Gray, 2000). Spirituality, on the contrary, may be a relevant component of life in organizations. Some authors consider it integral to new economy, knowledge-based organizations (e.g., Dehler \& Welsh, 2003). Hence our focus on spirituality. 
Sometimes workers are portrayed as being a-spiritual, at least on matters related to the workplace. At other times they are conceived as dependent people, waiting to receive the principles of spiritual or religious growth from their illuminated superiors. On still other occasions they are represented as individuals whose spiritual needs should be addressed by organizations. In the remainder of this section, these conceptions will be discussed in the context of their historical evolution.

To develop a systematic approach, we follow the historical periods in the evolution of management ideologies as portrayed by Barley and Kunda (1992). By “ideology” these authors refer to "a stream of discourse that promulgates, however unwittingly, a set of assumptions about the nature of the objects with which it deals” (Barley \& Kunda, 1992: 363). And they add that "all theories have an ideological component, since all theorists must adopt some ontological stance in order to proceed with their work" (p.363). Instead of considering the multiple aspects of management dealt with by Barley and Kunda, we draw on their chronology to specifically analyze the way each management ideology directly or indirectly addresses the issue of spirituality (for a summary, see Table 1). It is our contention that each ideology may be read through the lens of spirituality. It is with such a reading that we start below.

TABLE 1 ABOUT HERE

Industrial Betterment and the Childish Worker 
Industrial betterment prevailed as a dominant ideology between 1870 and 1900. This ideology emerged in the sequence of what was perceived as a lack of attention given by employers to the working conditions of people. Presumably as a result, riots and debauchery were part of organizational life (Wren, 1994). This state of affairs stimulated several agents, from religious ministers to industrialists, to propose a new approach to the management of people. As noted by Barley and Kunda (1992), one of the most prominent spokespersons of the industrial betterment movement was Washington Gladden, a Congregationalist minister who established a bridge between religion-based morality and industrial evolution.

As a management philosophy, industrial betterment was founded upon the belief that industry development depended on the perfecting of the moral qualities of the working people. This perfecting process should be conducted by managers. Organizational historians have noticed the abundance of inappropriate behaviors in many factories (Wren, 1994). In response to these behaviors, this movement tried to instill a moral code in workers. Partisans of this movement considered that character developed solely if the material and moral environment was proper, and their management was aimed at creating proper environments. To exemplify, we can consider the foundation of the Young Men's Christian Association (YMCA) by Cornelius Vanderbilt, the goal of which was to stimulate positive behavior among the workers of the railroad industry. Among the reasons why positive behaviors were deemed necessary, was the need to improve workforce reliability, and concomitantly to keep workers away from drinking alcohol. Management, spirituality and religion were thus explicit in this ideology. The image of infantile workers that emanated from the industrial betterment perspective required the guidance of enlightened-paternalistic managers. As Gladden (1876, quoted 
in Barley \& Kunda, 1992: 367) observed: “The Christian law is that we are to do good to all men as we have the opportunity; and certainly the employer's opportunity is among his employees.” This advice was translated into direct initiatives to educate the workforce, instilling in people the good virtues of frugality, industriousness and temperance, whose lack was said to be at the root of industrial unrest. Rather than improving the working conditions of people, managers were invited to improve the workingmen. "Bettered" employees would expectedly constitute a more docile workforce, more amenable to cooperation than to conflict, and more adequate to the attainment of profitability, "the final motif" as characterized by Barley and Kunda (1992: 368).

Scientific Management and the Homo Economicus

A similar attempt at improvement was pursued by scientific management. However, a significant difference emerged between this ideology and the previous: in this case it was the design of work rather than religious principles that would change the workingmen. Under scientific management, people would be directed by reason and the problems of industrial unrest would be appropriately, i.e., scientifically, managed. As noted by Shenhav (1995), in the Progressive period, business philosophy was crystallized around secular, engineering-based ideas, rather than around religious, philanthropic or paternalistic principles. Hence the importance of a philosophy oriented towards the maximal gains possible to employees. Managers would guarantee that their subordinates would have access to the maximum of economic gains by means of rationalized processes. Organizations were portrayed as rationalized sites, designed and managed according to a rule of rationality imported from the world of technique. This new mechanical world was not only instrumental but was also given an aesthetic value 
as suggested by the association between scientific management and the modernist movement in the arts (Guillén, 1997).

The human element was viewed in the organizational scenery as a nuisance, a source of uncertainty to be reduced through scientific means (Shenhav, 1999). The scientific way of solving problems could be easily contrasted with the industrial betterment perspective. According to Frederick Taylor, "Perhaps the most important of all the results attained was the effect on the workmen themselves. A careful inquiry into the condition of these men developed the fact that out of the 140 workmen only two were said to be drinking men (...) The fact is that a steady drinker would find it almost impossible to keep up with the pace which was set, so that they were practically all sober” (1911: 71-72).

The scientific approach to work reduced the spiritual element to a non-work issue. Workers did not expect charity from their employers. As noted by Taylor, "no selfrespecting workman wants to be given things, every man wants to earn things (Taylor, 1903, quoted in Barley \& Kunda, 1992: 371). The unshakable belief in science’s superiority prevented religion, and even spirituality, from having a relevant role, if any, to play in the management of organizations. In any case, as observed by Crainer (2000: 15), scientific management was not "immoral": "it simply subsumed moral considerations under the rationalist drive toward efficiency. People were fodder (...). In Taylor's mind management was an ascetic science rather than a humane one.”

The separation between science and religion was not necessarily as clear as suggested in the preceding argument. Some "scientific managers" showed clear betterment 
intentions. This was the case of Henry Ford, a key figure in the application of the scientific management movement. Ford combined a very strict management style on the shop floor with the defense of proper behaviors: he believed that men who lived “aright” would work “aright”. Hence his explicit ambition of “making men as well as automobiles” (Corbett, 1994, p.124). His religious principles constituted a curious combination of the religious zeal of industrial betterment, with the modernist faith in science and technology. Ford simultaneously designed factories according to the principles of scientific management and expected men "made by his factory" to show morally acceptable behaviors. This excluded, for example, gambling, extramarital sex, smoking and drinking alcohol, and included, after a 1932 edict, the growth of potatoes by employees in their gardens or courtyards, an interesting agricultural reminiscence in a man who escaped the destiny of being a farmer and who built his industrial empire upon the refusal of becoming a farmer (Kets de Vries, 1998). Employees’ behaviors were strictly controlled by a “Service Department”, both inside and outside the factory, including “midnight raids on employees' homes” (Corbett, 1994: 126) and other forms of management by fear.

\section{Human Relations and the Social Person}

Despite the dramatic productivity improvements introduced by scientific management (Drucker, 1999), some human problems emerged in Taylorist-Fordist factories, giving rise to the human relations movement (Mayo, 1945). The keyword in this school of thought was no longer morality or duty, as in the industrial betterment period, but efficiency, the watchword of scientific management. There were elements of spirituality, however, in the human relations approach. These included the need to belong, to gain self recognition, to find meaning in the organization. Wren (1994: 323) 
noted that evangelism and mysticism often characterized human relations training. The response of "human relationists" to people's need for meaning led to a new representation of the worker regarding spiritual/religious needs: the worker was then viewed as dependent and manipulable. Due to employees’ needs of belonging and social esteem, the organization should persuade its workers that it constituted the ideal environment for them. Such a concern with the management of people's wellbeing is certainly a respectable endeavor, and is still pursued today in such domains as the retention of knowledge workers (Alvesson, 2000) or the creation of authentizotic organizations (Kets de Vries, 2001). But there is more to some applications of the principles of the human relations school than making people feel better: as remarked by Wren (1994), supervisors in some companies were instructed to listen more than speak, to avoid moral recommendations and, in a somewhat perverse fashion, to hide their own emotions. In other words, they were taught how to manipulate the emotions of others in order to increase the meaningfulness of work and the need of belonging to the organization. The image of employees born of these descriptions was that of naive, dependent people, whose cooperation could be secured with soft tactics and emotional inclusion. Once again, the ultimate goal of the organization was profitability, which in this case was grounded on the equivalence between effective organizations and inclusive collectivities. Workers' social motives should thus be fulfilled for the sake of the organization's goals.

Systems Rationalism and the Cognitive Person

Systems rationalism marked the return of organization theory to "cold" thinking. The human relations school was criticized by some as the age of "goof-off” (Odiorne, 1965: 8), and the growing diffusion of computers and cybernetics led to a focus on cognitive 
science. Cognitive images of organizations pervaded the literature (Beer, 1972; Ilgen \& Klein, 1988) and the workforce was now portrayed as composed by calculative people, whose behavior should match the characteristics of the situation. Emotional and spiritual needs were again relegated to the background. Computer science brought a new perspective to management whose principles and functions were thought of as technical problems. The core of management education in elite universities was now centered on hard disciplines such as management science, accounting, statistics and operations research. Freed of the "touchy-feely" human factor, managers were developing the idea of the organization as a cybernetic system whose functioning depended on such tasks as forecasting, planning and controlling. The previous affectiveladen theories of motivation (Maslow, 1954) that were at the origin of the concept of positive organizational behavior (Wright, 2003), gave place to cognitive theories (Adams, 1965; Locke \& Latham, 1984; Vroom, 1964). In short, the organization was now presented as a cognitive system. Barley and Kunda (1992) observed that systems rationalism lacked an explicit model of the workforce. Another possible interpretation is to view the worker in systems rationalism as a "cognitive persona". As in the case of scientific management, human facets such as emotions and spirituality were absent. These dimensions have been virtually ignored and taken as irrelevant in the technical field of management.

Organizational Culture and Quality and the Member

The cold images of the person conveyed in the systems rationalism perspective were challenged by the ideology that followed: organizational culture and quality. The emergence of this ideology was due, on the one hand, to the global success of several 
Japanese companies (Pascale \& Athos, 1981) and, on the other hand, to the massive popularity of the concept of culture as a management tool (Deal \& Kennedy, 1982; Peters \& Waterman, 1982). As a consequence of the inception of the culture concept in management theory, companies rushed to create meaningful and shared values and missions (Collins \& Porras, 1994). The perspective of organizations as systems of meaning evokes a spiritual dimension of organizing. Taking organizations as systems of meaning (Pettigrew, 1979) inevitably leads to the conception of leaders as managers of the symbolic (Smircich \& Morgan, 1982). Through shared values, companies expected to turn employees into members, and the use of such terms as "we”, "us" or "our family" were used as synonymous for "The Organization”.

The idea of becoming a member of an organization has since been increasingly associated with the concept of citizenship (Manville \& Ober, 2003): organizations needed to treat their people as citizens and not only as cogs in the machine, infants or brains at the service of the company. The notion of membership appeared as particularly powerful to knowledge-intensive companies, in which professionals, due to their expertise and value, gained a bargaining power that forced the discovery of new ways of managing this “volunteer” workforce (Gratton \& Ghoshal, 2003).

Despite the potential advantages of emotional/spiritual inclusion brought about by the culture/quality movement, there was a flip side in this ideology. As pointed out by many authors (e.g., Barker, 1993; Pfeffer, 1997), culture can be a mechanism of control as much as a process of inclusion. People can be forced, for instance, to join "happy family” organizations (Boje, 1995), which reveals the potential paradox involved in the management of spiritual inclusion. It is certainly not by coincidence that "spiritual 
training” was so frequent in Japanese companies embracing a quality management philosophy, whose implementation is facilitated by attitudes of reality-acceptance, perseverance and cooperation (Clegg, 1992). Due to increasing levels of professionalism, organizations working in the knowledge economy felt the need to replace their obtrusive control mechanisms with non-obtrusive or transparent controls, with means of organizational design (Sewell, 1998), peer pressure (Barker, 1993), or hagiographic leadership (Kamoche, 2003). Leaders became the high priests of their organizations, leading the "membership" through a number of rituals with quasireligious qualities. As such, what may be viewed as a mechanism of liberation may also be taken as a means for tightening the iron cage, as "corporate culturalism" "subsumes the individual within an artificially imposed and instrumentally oriented collectivity” (Hancock, 1997: 102).

From the above discussion, two axes can be derived to proceed to a theoreticallyinformed analysis of organizational spirituality: the model of the person as dependent or independent and the model of management as spiritual or secular practice. The resulting typology is presented in the next section.

\section{SPIRITUALITY, PEOPLE, AND MANAGEMENT}

Management ideologies can be analyzed with reference to the intersection of two major influences: (1) a pendulum swing between spiritual and secular approaches; and (2) a progression from the view of workers as dependent to independent. We consider that workers are taken as dependent when they are viewed as not being able to devise the best for themselves. If that is the case, someone (e.g., the manager) has to take care of them (e.g., to help them escape from undesirable behaviors). People are viewed as 
independent when they are expected to make their own autonomous choices. They are treated as organizational citizens, not as passive-reactive employees. To understand the shift from the first to the second view, we have to consider the transition from Taylorist to post-Taylorist organizations. In the first case, with the exception of the professional elite, workers were expected to execute orders as obediently and diligently as possible. Passive dependence was congruent with the organizational model. In post-Taylorist organizations, employees became expected to be active and intelligent participants. In the works of Aktouf (1992: 411-412) the employee as a "passive cog” gave place to the “active and willing accomplice”. In other words, dependence gave place to independence. Regarding the spirituality dimension, management is represented as spiritual practice when it assumes that there is a spiritual component in the managerial activity that should be taken as an integral part of the profession. Management is viewed as secular practice when it is taken as a-spiritual and limits its influence to the work sphere of an individual's life.

Combining these two dimensions (model of management as spiritual or secular and model of the person as dependent or independent) results in a framework that supports a theoretical analysis of organizational spirituality. Such a framework, presented in Table 2, helps us to understand why organizational spirituality may be a source of human development and also a mechanism of compliance. This is a relevant aspect for the analysis of organizational spirituality considering that: (1) worker compliance is a crucial topic in organizational analysis (Bendix, 1956), with spiritual indoctrination constituting a further possibility for achieving compliance through the apparent search for inner meaning (Kamoche, 2003); (2) the search for inner meaning is frequently portrayed as constituting the essence of organizational spirituality. As such, our 
typology allows an interpretation of organizational spirituality from multiple perspectives and advances the topic beyond anecdote and conviction. Four types of organizations will be discussed next, resulting from the combination of the two variables considered: the soulful organization, the ascetic organization, the holistic organization and the professional organization.

\section{INSERT TABLE 2 ABOUT HERE}

The Soulful Organization

The explicit association between organizational spirituality and organizational performance is a recent phenomenon in the organizational literature. Bolman and Deal (1995) were among the authors suggesting that spiritualism is good for performance. Spirituality is therefore viewed in this perspective as an organizational resource (Bell \& Taylor, 2003) or even as the ultimate source of competitive advantage (Overell, 2003). The organizational spirituality as resource perspective opens up many avenues for research, consulting and practice, given that it promises to fuse organizational interest with individual growth and development. In this case, organizations reclaim "the soul" of the individual, more than the body (Kunda, 1992). Managing with soul implies the alignment between the organizational vision and employees' sense of purpose. If there was already a research stream on the organization of exclusion (Martin, 1994), the "managing with soul” perspective represents an effort to understand the organization of total inclusion. Martin et al.'s (1998) study of The Body Shop provides an example of a soulful organization. 
Soulful organizations may take different shapes, from new age organizational thinking (Nichols, 1994) to alienating systems of control (Kamoche, 2003). They can also be marked by the inclusion of "love" in the organizational terminology. The arrival of "love" to the CEO vocabulary, or what Kellaway (2003) called "love by internal memo" is an interesting feature of some soulful organizations: "This emotional language is a new kind of patois spoken almost exclusively by chief executives. They are all speaking it, yet everyone else (...) hates it” (Kellaway, 2003: 5). Maybe not everyone hates love management. As reported by one shop clerk at The Body Shop, “The Body Shop is nice because I don't feel like I have to fit some kind of mold. At The Body Shop I feel I can be more myself.” (Martin, Knopoff \& Beckman, 1998: 449). This sense of authenticity, often combined with praise for the singularity of the organization (Cunha, 2002), may be of high instrumental value. As noted by Martin et al. (1998: 461), people in this kind of environment may be stimulated to think that "I can do my best work when I can be myself.” For some employees at The Body Shop reported in the same study, however, the need to show emotional expressiveness was something uncomfortable, if not manipulating, as when people were required to seem relaxed, cheerful and happy, even when in fact they might be feeling otherwise.

Soulful, inclusive environments can be a source of plenitude for some people, and a totalitarian experience for other people. They can be thought of as a path to a meaningful organizational life, but also as the imposition of pastoral power, depending on the interpretation. For this reason companies that have been too successful in their efforts to create bonds with employees tend to be viewed with both fascination and fear (Pratt, 2000a). When employees in this type of organizations perceive the existence of 
discrepancies between the rhetoric and the practice of managers, the soulful approach may be a path to organizational cynicism (Dean, Brandes, \& Dharwadkar, 1998).

The management of inclusion in the soulful organization can be achieved through several ways: organizational missions and visions, “cult managers”, transformational leaders, practices of indoctrination, physical space (e.g., creating spaces for praying and meditation), the creation of liminal spaces conducive to spiritual awareness (e.g., management retreats), and even best spiritual practices (Mitroff \& Denton, 1999b). Taken to the extreme, this perspective may easily turn into a source of "colonization" (Bell \& Taylor, 2003) of every life domain by a workplace that is presented as able to fulfil every human need, founded on the religious-based belief that work is an act of virtue. Organizations imbued with the sacred power arising from their liberation force may become total institutions or ideological fortresses (Pratt, 2000b), imposing their worldviews on workers through an overarching system of meaning, impervious to attack by people who might oppose it. Parker (1997: 83) questions the truthfulness of organization spiritual inclusion as he considers that members may "only be able to echo the master's voice not to challenge it”.

The Ascetic Organization

The ascetic organization combines the perspective of management as secular practice and a view of the worker as dependent. These organizations can be viewed as being founded upon rationality and technique. They may develop when a professional and highly-qualified group of managers leads a less-qualified workforce. The rational orientation precludes the will to manage the spiritual side of the organization; in turn, the company is managed according to the principles of technique and rationality. The 
management project is viewed here as an ascetic one, in the sense that it should be austere, rigorous, and efficiency-oriented.

The focus on the technical a-spiritual side of the organization may bring process clarity and goal orientation. These, in turn, may facilitate goal attainment, being potentially functional from an effectiveness perspective. Goal clarity, as evidenced by goal setting theory, may facilitate good performance (Latham, 2000). There is one likely downside, however, in the ascetic approach to organizing. As suggested by Peters and Waterman (1982), organizations where people share a common set of values and experience some kind of emotional bond with the company, may stimulate a sense of membership that will be valuable internally as well as a competitive tool in the business arena. Emery and Thorsrud (1976) claimed that in order to satisfy psychological needs, jobs must provide employees with a sense that they are contributing to social welfare in a meaningful way (Ellsworth, 2002). This contribution may not be explicit in the ascetic organization.

Ascetic organizations, due to their nature, may in fact develop psychological contracts of the transactional type (Rousseau, 1995). Given the link between organizational flexibility and the willingness of the employees to exhibit conduct of the organizational citizenship type, ascetic organizations may not be the most competent in the elicitation of extra-role behaviors (Tepper, 2003). Additionally, people may feel themselves as employees, not as members (Drucker, 2002), given the combination of a lack of emotional inclusion and the potentially low autonomy and empowerment granted to workers in organizations where they are viewed as a dependent workforce (Gilbreath, 2004). 
The Holistic Organization

The search for the best companies to work for (Levering \& Moskowitz, 1993) usually points to organizations that are spiritual in the sense that they try to create meaning in an expressive fashion. These organizations can be distinguished from the previous organizational types because they emphasize the individual, not the organization. There is a clear, explicit and voluntary investment in development practices. It is the individual's development (on the personal, spiritual and professional grounds) that supports organization development. As such, organizational efforts should emphasize personal growth and progress. Consequently, a focus on issues such as work/non-work balance, work-family conflict, and individual psychological well-being, are sources of meaning and development. The previous characteristics clearly evoke Kets de Vries’ (2001) concept of the authentizotic organization or Gratton's (2004) notion of the democratic enterprise. In spite of the potentially thin line separating the authentizotic organization and soulful companies, the distinction lies in the spiritual locus: the individual in this case, the organization in the former.

The Professional Organization

When the organization does not manage its spiritual side and the independent view of the worker prevails, it can be described as professional. This perspective corresponds to the notion that the business of business is business (Friedman, 1970). As such, organizations should be treated as instrumental, a-spiritual and legally respectful places, where ethical cultures and behaviors may prosper regardless of the management of spirituality (Victor \& Cullen, 1988). Work organizations, in this view, have not been 
conceived to satisfy the spiritual and religious needs of people. The fulfillment of those needs is the mission of religious and voluntary organizations, not of business firms. This position is thus closer to the scientific management or system rationalism approaches, with their emphases on the instrumental side of the organization. Good management does not necessarily imply an explicit focus on the creation of "spiritual workplaces" (Pfeffer, 1994; Lee \& Miller, 1999). It is through the adequate management of people that organizations may aspire to be viewed as meaningful places (Pfeffer, 2003).

In this organization, spiritual development is not the object of a managed approach, but rather an individual initiative. Individuals will pursue their personal motives and the organization will be as ethical as its members. This is the place where people like Nick Leeson will find opportunities to “succeed”. When personal unethical agendas multiply, corporate scandals may erupt. But this is also a potentially fruitful working environment for the voluntary professional described by Gratton and Ghoshal (2003), whose professional ethic derives more from personal reputation and professional socialization than from organizational indoctrination and control.

\section{CONCLUSION}

In their review of the evolution of management thought, Barley and Kunda (1992: 363) stated that "all theories have an ideological component.”. To this, we added that all theories have a spiritual component. Hence the analysis of the spiritual component of the management ideologies identified by Barley and Kunda. With this approach, we have contributed to the construction of a theory of organizational spirituality "that goes beyond prescription and proselytizing” (Kamoche, 2003: 6). We did so in this article in two ways. 
First, we suggested that organizational ideologies do have a spiritual component: some by presence, with more or less clear guidelines on how to deal with spirituality when not even with religion (which is the case of "Christian organizations" or "spiritual communities”, see Pratt, 2000b); others by exclusion. Considering organizations as aspiritual places is indeed a strong position regarding workplace spirituality. The debate on the meaning and utilization of spirituality in organizational settings is an important one considering the intensification in contemporary societies of the recourse to technologies of the self (i.e. means by which people, by themselves or with the help of other people, act upon their bodies, thoughts and conduct in order to attain happiness, fulfillment, success, wealth or wisdom) (Covaleski, Dirsmith, Heian, \& Samuel, 1998). Organizational spirituality qualifies as a technology of the self, whose reach is still to be investigated. We have contributed to this debate through the construction of a theoretical framework that considers both the liberating and constraining forces potentially present in the notion of organizational spirituality.

Second, we have contributed to the literature by suggesting that spiritual workplaces of the various types are not intrinsically good or bad, in the same sense that (a)spiritual organizations are not necessarily positive or negative. We do not conceive organizational spirituality as the most recent panacea for solving the moral problems of contemporary corporations (see also Boyle \& Healy, 2003), but as a relevant dimension of organization life, which should be studied as any other topic in the research agenda. There may be many problems of the ethical/moral type in today's firms (Handy, 2002; Mintzberg, Simons \& Basu, 2002) leading to a crisis of confidence in corporations (Child, 2002), but, as discussed here, it is far from clear whether the spiritual remedy is a necessary or a sufficient condition to address them. 


\section{REFERENCES}

Adams, J.S. 1965. Inequity in social exchange. In L. Berkowitz (Ed.), Advances in Experimental Social Psychology Vol.2: 267-299. New York: Academic Press.

Aktouf, O. 1992. Management and theories of organization in the 1990s: Toward a critical radical humanism? Academy of Management Review, 17: 407-431.

Alvesson, M. 2000. Social identity and the problem of loyalty in knowledge-intensive companies. Journal of Management Studies, 37: 1101-1123.

Arthur, M.B., \& Rousseau, D. 2001. Conclusion: A lexicon for the new organizational era. In M.B. Arthur \& D.M. Rousseau (Eds.), The boundaryless career: A new employment principle for a new organizational era: 370-382. New York: Oxford University Press.

Ashmos, D.P., \& Duchon, D. 2000. Spirituality at work: A conceptualization and measure. Journal of Management Inquiry, 9: 134-145.

Barker, J.R. 1993. Tightening the iron cage: Concertive control in self-managing teams. Administrative Science Quarterly, 38: 400-437.

Barley, S.R., \& Kunda, G. 1992. Design and devotion: Surges of rational and normative ideologies of control in managerial discourse. Administrative Science Quarterly, 37: 363-399.

Beer, S. 1981. Brain of the firm (2nd ed.). New York: John Wiley \& Sons.

Bell, E., \& Taylor, S. 2003. The elevation of work: Pastoral power and the new age work ethic. Organization, 10: 329-349.

Bendix, R. 1956. Work and authority in industry. New York: Wiley.

Boje, D.M. 1995. Stories of the storytelling organization: A postmodern analysis of Disney as Tamara-Land. Academy of Management Journal, 38: 997-1035. 
Bolman, L., \& Deal, T.E. 1995. Leading with soul: An uncommon journey of spirit. San Francisco: Jossey Bass.

Boyle, M.V., \& Healy, J. 2003. Balancing mysterium and onus: Doing spiritual work within emotional and emotional-laden organizational contexts. Organization, 10: 351-373.

Burroughs, S.M., \& Eby, L.T. 1998. Psychological sense of community at work: A measurement system and explanatory framework. Journal of Community Psychology, 26: 509-532.

Cash, K.C., \& Gray, G.R. 2000. A framework for accommodating religion and spirituality in the workplace. Academy of Management Executive, 14(3): 124133.

Child, J. 2002. The international crisis of confidence in corporations. Academy of Management Executive, 16(3): 142-144.

Clegg, S.R. 1992. Postmodern management? Journal of Organizational Change Management, 5: 31-49.

Collins, J.C., \& Porras, J.I. 1994. Built to last: Successful habits of visionary companies. New York: Harper Business.

Corbett, J.M. 1994. Critical cases in organisational behaviour. London: Macmillan.

Covaleski, M.A., Dirsmith, M.W., Heian, J.B., \& Samuel, S. 1998. The calculated and the avowed: Techniques of discipline and struggles over identity in big six public accounting firms. Administrative Science Quarterly, 43: 293-327.

Crainer, S. 2000. The management century. San Francisco: Jossey Bass.

Cunha, M.P. 2002. “The best place to be”: Managing control and employee loyalty in a knowledge-intensive company. Journal of Applied Behavioral Science, 38: 401415. 
Deal, T.E., \& Kennedy, A. 1982. Corporate culture: The rites and rituals of corporate life. Reading, MA: Addison Wesley.

Dean, J.W., Brandes, P. \& Dharwadkar, R. 1998. Organizational cynicism. Academy of Management Review, 23: 341-352.

Dehler, G.E., \& Welsh, M.A. 2003. The experience of work and the new workplace. In R.A. Giacalone \& C.L. Jurkiewicz (Eds.), Handbook of workplace spirituality and organizational performance:108-122. New York: M.E. Sharpe.

Drucker, P.F. 2002. They're not employees, they're people. Harvard Business Review, February: 70-77.

Drucker, P.F. 1999. Knowledge-worker productivity: The biggest challenge. California Management Review, 41(2): 79-94.

Ellsworth, R.R. 2002. Leading with purpose. Stanford, CA: Stanford Business Books.

Emery, F., \& Thorsrud, E. (1976). Democracy at work: The report of the Norwegian industrial democracy program. Leiden: Martinus Nijhoff.

Friedman, M. 1970. The social responsibility of business is to increase its profits. New York Times Magazine, September 13: 32.

Gilbreath, B. 2004. Creating healthy workplaces: The supervisor's role. In C.L. Cooper \& I.T. Robertson (Eds.), International Review of Industrial and Organizational Psychology Vol.19: 93-118. Chichester: John Wiley \& Sons.

Gratton, L., \& Ghoshal, S. 2003. Managing personal human capital. New ethos for the ‘volunteer’ employee. European Management Journal, 21(1): 1-10.

Guillén, M. 1997. Scientific management's lost aesthetic: Architecture, organization, and the Taylorized beauty of the mechanical. Administrative Science Quarterly, 42: $682-715$. 
Hancock, P.G. 1997. Citizenship or vassalage? Organizational membership in the age of unreason. Organization, 4: 93-111.

Handy, C. 2002. What's a business for? Harvard Business Review, December: 49-55.

Ilgen, D.R., \& Klein, H.J. 1988. Organizational behavior. Annual Review of Psychology, 40, 327-351.

Kamoche, K.N. 2003. Organizational spiritualism: Toward a critical analysis. Presented at the Academy of Management Conference, Seattle, WA.

Kellaway, L. 2003. Tell me, please tell me, the truth about love. Financial Times, July 21: 5 .

Kets de Vries, M.F.R. 1998. The leadership mystique. Academy of Management Executive, 8(3): 73-92.

Kets de Vries, M.F.R. 2001. Creating authentizotic organizations: Well-functioning individuals in vibrant companies. Human Relations, 54: 101-111.

Kunda, G. 1992. Engineering culture: Control and commitment in a high tech corporation. Philadelphia, PA: Temple University Press.

Latham, G.P. 2000. Motivate employee performance through goal-setting. In E.A. Locke (Ed.), Handbook of principles of organizational behavior: 107-119). Oxford: Blackwell.

Lee, J., \& Miller, D. 1999. People matter: Commitment to employees, strategy and performance in Korean firms. Strategic Management Journal, 20: 579-593.

Levering, R., \& Moskowitz, M. 1993. The 100 best companies to work for in America. New York: Doubleday.

Locke, E.A., \& Latham, G. P. 1984. Goal setting: A motivational technique that works. Englewood Cliffs, NJ: Prentice-Hall. 
Manville, B., \& Ober, J. 2003. A company of citizens. Boston, MA: Harvard Business School Press.

Martin, J. 1994. The organization of exclusion: The institutionalization of sex inequality, gendered faculty jobs, and gendered knowledge in organizational theory and research. Organization, 1: 401-431.

Martin, J., Knopoff, K., \& Beckman, C. 1998. An alternative to bureaucratic impersonality and emotional labor: Bounded emotionality at The Body Shop. Administrative Science Quarterly, 43: 429-469.

Maslow, A. 1954. Motivation and personality. New York: Harper \& Row.

Mastenbroek, W. 1996. Organizational innovation in historical perspective: Change as duality management. Business Horizons, 39(4): 5-14.

Mayo, E. 1945. The social problems of an industrial civilization. Boston: Harvard University.

McCormick, D.W. 1994. Spirituality and management. Journal of Managerial Psychology, 9(6): 5-8.

McGregor, D. 1960. The human side of entrerprise. New York: McGraw-Hill.

Micklethwait, J., \& Wooldridge, A. 2003. The company: A short history of a revolutionary idea. New York: The Modern Library.

Mintzberg, H., Simons, R. \& Basu, K. 2002. Beyond selfishness. Sloan Management Review, Fall: 67-74.

Mitroff, I.I. 2003. Do not promote religion under the guise of spirituality. Organization, 10: $375-382$.

Mitroff, I. I., \& Denton, E. A. 1999a. A study of spirituality in the workplace. Sloan Management Review, Summer: 83-91. 
Mitroff, I. I., \& Denton, E. A. 1999b. A spiritual audit of corporate America. San Francisco: Jossey Bass.

Nichols, M. 1994. Does new age business have a message for managers? Harvard Business Review, March-April: 52-60.

Odiorne, G.S. 1965. Management by objectives: A system of managerial leadership. Marshfield, MA: Pitman.

Overell, S. 2003. Spirituality in business: A reconnection with core values. Financial Times, September 20: 11.

Parker, M. 1997. Organizations and citizenship. Organization, 4: 75-92.

Pascale, R.T., \& Athos, A.G. 1981. The art of Japanese management. New York: Simon \& Schuster.

Peters, T., \& Waterman, R. 1982. In search of excellence: Lessons from America's best-run corporations. New York: Harper \& Row.

Pettigrew, A. 1979. On studying organizational cultures. Administrative Science Quarterly, 24: 570-581.

Pfeffer, J. 1994. Competitive advantage through people: Unleashing the power of the work force. Boston, MA: Harvard Business School Press.

Pfeffer, J. 1997. New directions in organization theory. New York: Oxford University Press.

Pfeffer, J. 2003. Business and the spirit: Management practices that sustain values. In R.A. Giacalone \& C.L. Jurkiewicz (Eds.), Handbook of workplace spirituality and organizational performance: 29-45. New York: M.E. Sharpe.

Pratt, M.G. 2000a. The good, the bad and the ambivalent: Managing identification among Amway distributors. Administrative Science Quarterly, 45: 456-493. 
Pratt, M.G. 2000b. Building an ideological fortress: The role of spirituality, encapsulation and sensemaking. Studies in Cultures, Organizations and Societies, 6: 35-69.

Rousseau, D.M. 1995. Psychological contracts in organizations. Understanding written and unwritten agreements. Beverly Hills, CA: Sage.

Sandelands, L.E. 2003. The argument for God from organization studies. Journal of Management Inquiry, 12: 168-177.

Sewell, G. 1998. The discipline of teams: The control of team-based industrial work through electronic and peer surveillance. Administrative Science Quarterly, 43: 397-428.

Shenhav, Y. 1995. From chaos to systems: The engineering foundations of organization theory, 1879-1932. Administrative Science Quarterly, 40: 557-585.

Shenhav, Y. 1999. Manufacturing rationality. The engineering foundations of the managerial revolution. New York: Oxford University Press.

Smircich, L., \& Morgan, G. 1982. Leadership: The management of meaning. Journal of Applied Behavioral Science, 18: 257-273.

Tepper, B.J. 2003. Organizational citizenship behavior and the spiritual employee. In R.A. Giacalone \& C.L. Jurkiewicz (Eds.), Handbook of workplace spirituality and organizational performance: 181-190. New York: M.E. Sharpe.

Tinsley, D.B. 2002. The Proverbial manager. Business Horizons, 45 (SeptemberOctober): 27-34.

Vaill, P.B. 1998. Spirited leading and learning. Process wisdom for a new age. San Francisco: Jossey Bass.

Victor, B., \& Cullen, J. B. 1988. The organizational bases of ethical work climates. Administrative Science Quarterly, 33: 101-125. 
Vroom, V.H. 1964. Work and motivation. New York: Wiley.

Wren, D.A. 1994. The evolution of management thought ( $4^{\text {th }}$ ed.). New York: John Wiley \& Sons.

Wright, T.A. 2003. Positive organizational behavior: An idea whose time as truly come. Journal of Organizational Behavior, 24: 437-442.

Wright, T.A., \& Cropanzano, R. 2000. Psychological well-being and job satisfaction as predictors of job performance. Journal of Occupational Health Psychology, 5(1): 84-94. 
TABLE 1

Ideology, Model of the Person and Implications for Organizational Spirituality

\begin{tabular}{|c|c|c|}
\hline Ideology & Model of the person & Model of the management \\
\hline Industrial betterment & \begin{tabular}{l}
\multicolumn{1}{c}{ Dependent } \\
Employees are \\
unable to make the good \\
choices. Vulnerable to \\
immoral behaviors. \\
\end{tabular} & $\begin{array}{l}\text { Spiritual } \\
\text { Employees must be guided } \\
\text { by their bosses to a lifestyle } \\
\text { congruent with Christian } \\
\text { values. }\end{array}$ \\
\hline Scientific management & $\begin{array}{l}\text { Unable to make the good } \\
\text { choices. Egoistic and } \\
\text { externally motivated by } \\
\text { economic gains. }\end{array}$ & \begin{tabular}{l}
\multicolumn{1}{c}{ Secular } \\
Managers must create \\
scientifically-designed \\
organizational contexts. \\
These will give access to \\
better outcomes to \\
employees.
\end{tabular} \\
\hline Human relations & \begin{tabular}{l}
\multicolumn{1}{c}{ Dependent } \\
Employees are unable to \\
make the good choices. \\
Childish and vulnerable to \\
manipulation. Motivated by \\
social belonging.
\end{tabular} & $\begin{array}{l}\text { Managers must view } \\
\text { organizations as spiritual } \\
\text { climates where people feel } \\
\text { included. }\end{array}$ \\
\hline Systems rationalism & $\begin{array}{l}\text { People as rational decision } \\
\text { makers. Competent people } \\
\text { collect, process and make } \\
\text { use of information. }\end{array}$ & \begin{tabular}{l}
\multicolumn{1}{c}{ Secular } \\
Managers should design \\
organizations as \\
information processing \\
machines, operated by \\
cognitive personae.
\end{tabular} \\
\hline Organizational culture & \begin{tabular}{l}
\multicolumn{1}{c}{ Independent } \\
The need to increase \\
autonomy and participation \\
must be complemented with \\
invisible and acceptable \\
mechanisms of control. \\
Culture may be one of such \\
mechanisms, allowing the \\
combination of independent \\
action and organizational \\
control.
\end{tabular} & $\begin{array}{l}\text { The organization can be } \\
\text { designed as a source of } \\
\text { personal identity. } \\
\text { Employees are invited to } \\
\text { become members and to } \\
\text { devote both their hearts and } \\
\text { minds to the organization. }\end{array}$ \\
\hline
\end{tabular}


TABLE 2

Model of Management and Model of the Person

\begin{tabular}{|l|l|l|}
\cline { 2 - 4 } \multicolumn{1}{l|}{} & Dependent person & Independent person \\
\hline $\begin{array}{l}\text { Management } \\
\text { spiritual practice }\end{array}$ & $\begin{array}{l}\text { Source of liberation: Search for } \\
\text { integration between individuals and the } \\
\text { firm } \\
\text { Source of alienation: Spiritual imposition } \\
\text { and intrusion, organizational cynicism }\end{array}$ & $\begin{array}{l}\text { The holistic organization } \\
\text { Source of liberation: integral attention to } \\
\text { human needs, inner meaning at work } \\
\text { Source of alienation: the organization as } \\
\text { religion }\end{array}$ \\
\hline $\begin{array}{l}\text { Management } \\
\text { secular practice ascetic organization }\end{array}$ & $\begin{array}{l}\text { Source of liberation: rationality and } \\
\text { clarity } \\
\text { Source of alienation: narrow view of the } \\
\text { organization's purposes }\end{array}$ & $\begin{array}{l}\text { The professional organization } \\
\text { Source of liberation: no spiritual } \\
\text { demands placed on employees; "pastoral } \\
\text { power” is not exerted over the individual } \\
\text { Source of alienation: Calculative bonds } \\
\text { with the organization, self-directed } \\
\text { behaviors, social detachment }\end{array}$ \\
\hline
\end{tabular}

